\title{
Narrativa da vida em fuga na autobiografia de um refugiado sírio.
}

Daniele dos Santos de Souza ${ }^{l}$

Fernando Zolin-Vesz $z^{2}$

\begin{abstract}
Resumo: A Guerra Civil na Síria desde 2011 e a crise humanitária de refugiados têm tido destaque no enredo de autobiografias de refugiados sírios no mercado editorial internacional. Este artigo busca analisar o discurso (neo)orientalista na autobiografia Eu venho de Alepo, do refugiado sírio Joude Jassouma, a fim de apresentar possíveis entendimentos sobre os efeitos produzidos sobre o refugiado sírio e a relação Ocidente e Oriente. O estudo do discurso se ampara nas concepções foucaultianas de formação discursiva, enunciado, relações de poder, verdade e poder (FOUCAULT, 2008; FOUCAULT, MACHADO, 2012). As perguntas que nortearam a pesquisa foram: como o refugiado sírio é apresentado em Eu venho de Alepo? Quais os sentidos produzidos sobre a relação Ocidente e Oriente na referida obra?. Os resultados sugerem que Eu venho de Alepo se afilia à formação discursiva (neo)orientalista na medida em que constrói o Ocidente como o espaço da liberdade e da paz e o Oriente como o espaço da guerra e barbárie. Os efeitos de sentido produzidos são diversos, pois, assim como sistemas de pensamento tais quais o (neo)orientalismo reforçam a violência estrutural e marginalizam outros modos de vida, a questão do refúgio pode incentivar a solidariedade voluntária.
\end{abstract}

Palavras-chave: Refugiado. Síria. Autobiografia. Neo-orientalismo.

\section{Introdução}

Os conflitos na Síria após a Primavera Árabe - onda de protestos que ocorreu entre 2010 e 2011 em diversos países do Oriente Médio e Norte da África -, ou ainda mais precisamente após a insurreição síria em 2011 (COSTA, 2016), impulsionaram uma crescente afluência migratória de sírios rumo a diferentes países, sobretudo na Europa. A chamada “crise humanitária de refugiados" tem se tornado tópico frequente não apenas das produções

\footnotetext{
${ }^{1}$ Mestre e doutoranda em Estudos de Linguagem pela Universidade Federal de Mato Grosso, Técnica em Assuntos Educacionais na mesma instituição.E-mail: daniele.souza@outlook.com

${ }^{2}$ Doutor em Letras e Linguística pela Universidade Federal de Goiás, Professor do Departamento de Letras e do Programa de Pós-Graduação em Estudos de Linguagem da Universidade Federal de Mato Grosso. E-mail: fernando_vesz@hotmail.com
}

Gláuks: Revista de Letras e Artes - jan/jun. 2019 - Vol. 19, $N^{o} 1$ 
midiáticas, noticiários e reportagens, mas também no enredo de diferentes obras ficcionais e autobiográficas nos últimos cinco anos. A proliferação de narrativas de vida que colocam o refugiado como personagem ou como aquele que conta o seu testemunho coloca em evidência tanto a temática do refúgio quanto a escolha do gênero autobiografia ou romance de autoficção.

Conforme Souza (2018), a experiência do refúgio, enquanto enredo central, tem conquistado o mercado editorial, que, no último quinquênio, tem popularizado obras como $E u$ venho de Alepo, de Joude Jassouma; Nujeen, de Nujeen Mustafa; Uma esperança mais forte que o mar, de Melissa Fleming; A memória do mar, de Khaled Hosseini; Diários de Raqqa, de Samer; O menino de Alepo, de Sumia Sukkar; Lua de Mel em Kobane, de Patrícia Campos Mello; Querido Mundo, de Bana Alabed; Escape from Aleppo, de Naheed Hasnat Senzai; The Battle for Home: The Memoir of a Syrian Architect, de Marwa al-Sabouni; The morning they came for us: dispatches from Syria, de Janinie Di Giovanni; The doodler of Dimashq, de Kirthi Jayakumar; The home that was our country: a memoir of Syria, de Alia Malek; No turning back: life, loss and hope in wartime Syria, de Rania Abouzeid; The boy on the beach, de Tima Kurdi; Und die Vögel werden singen: Ich, der Pianist aus den Trümmern, de Aeham Ahmad, dentre outros.

Dentre tal universo de produções, o sucesso das autobiografias de refugiados sírios, comercializadas em livrarias virtuais de grande alcance, demonstra que há um interesse internacional por tal assunto, o que delineia um fenômeno que não se limita a fronteiras préestabelecidas. O fascínio por tais narrativas coaduna com o interesse ocidental, visto ser este seu principal público alvo, de conhecer esse outro tão diferente, o qual está cada vez mais presente em seu próprio território. A temática "crise dos refugiados" e a fuga de grandes fluxos do Oriente Médio rumo ao Ocidente adquire novas perspectivas, justificativas e tentativas de escrita da História por meio de tais produções literárias, que, por sua vez, produzem sentidos sobre a relação Ocidente e Oriente, sobre o árabe e a situação de refúgio, além de permitir novas visões sobre o mundo contemporâneo.

Neste sentido, a fim de entender de que maneira o refugiado é apresentado nestas autobiografias e como se constróem discursivamente os sentidos sobre a relação Ocidente e Oriente, analisamos neste artigo o discurso (neo)orientalista na autobiografia Eu venho de Alepo: Itinerário de um refugiado de autoria, de Joude Jassouma e escrita colaborativa de 
Laurence de Cambronne. De maneira a nortear a análise proposta, o estudo circulará em torno das questões: como o refugiado sírio se constrói em Eu venho de Alepo? Quais os sentidos produzidos sobre a relação Ocidente e Oriente?

A organização do artigo está compreendida em 4 seções, a saber: Perspectiva discursiva e autobiografia: construindo percursos analíticos, em que apresentamos de que maneira construímos um percurso analítico transdisciplinar que nos permite observar os efeitos de sentidos discursivos produzidos na autobiografia selecionada, a seção Orientalismo e neo-orientalismo: distinções e similitudes, em que apresentamos de forma suscinta as diferenças e semelhanças entre o discurso orientalista (SAID, 2016) e o (neo)orientalista (DABASHI, 2017) de modo a discutir de que maneira a autobiografia Eu venho de Alepo se insere na malha discursiva neo-orientalista e ampliamos com discussões pertinentes ao (neo)orientalismo (BASTOS, 2016; BAUMAN, 2017a; 2017b; COSTA, 2016), a seção Ocidente paradisíaco e Oriente infernal no relato de Jassouma, na qual analisamos alguns dos excertos extraídos da obra em questão, e, por fim, a seção de considerações finais intitulada Um momento purgatorial: ponto ou vírgula.

\section{Perspectiva discursiva e autobiografia: construindo percursos analíticos}

O diário escondido e trancado com um cadeado traz em suas páginas a narrativa de vida de seu autor, ou ainda o seu ponto de vista, suas emoções e percepções a respeito de tudo aquilo que o cerca. Encontrar esse diário e destrancá-lo, folheá-lo, permite o contato com os fragmentos dessa vida outra, com os relatos diários de alguém sobre diferentes assuntos, geralmente em uma escrita franca e livre. Haverá sempre a curiosidade em verificar o que um outro alguém escreve em seu diário, mas é, geralmente, para si que o autor escreve seu diário íntimo (LEJEUNE, 2014). A intimidade escondida e trancada do diário íntimo contrasta com diversos outros tipos de narrativas autobiográficas, sobretudo a autobiografia produzida para ser exposta em uma prateleira, comercializada, traduzida para diferentes idiomas e transportada para diferentes espaços e continentes. Em ambas situações, o que parece encantar o leitor de narrativas autobiográficas, seja aquele que encontra um diário que nunca deveria ser descoberto, seja aquele que se fascina por tal gênero literário e o procura nos corredores de

\footnotetext{
Gláuks: Revista de Letras e Artes - jan/jun. 2019 - Vol. 19, $N^{o} 1$
} 
livrarias ou bibliotecas, é a possibilidade do contato com um relato fiel de quem realmente viveu o que ali se narra.

$\mathrm{Na}$ autobiografia, há a utilização de procedimentos que objetivam certificar o leitor de que o relato é autêntico, tais como a assinatura, a afirmação da identidade do autor, o modo de escrita, além do efeito contratual que requer também um modo de leitura (LEJEUNE, 2014). A busca pelo relato mais real e dotado de convencimento do leitor sobre a veracidade do que é narrado se torna mais efetiva através das autobiografias, pois o leitor é convencido de que tal produção não é uma ficção, mas, sim, um relato verdadeiro, que aconteceu no mundo concreto. Sendo assim, ser seduzido por Sherazade e suas narrativas nas fábulas do Livro das mil e uma noites ou ser convencido da fidedignidade do relato de um refugiado sírio, cuja fotografia estampa a capa de um livro, são condições de satisfação dos diferentes gêneros em seus propósitos para com o leitor.

Em Eu venho de Alepo, bem como em diversas obras autobiográficas centradas na temática de refugiados sírios, notamos a verdade como um valor que agrega visibilidade a essas histórias: conhecer a vida de pessoas que superaram a situação de fuga de seu país torna visíveis, memoráveis e reais tais existências. Para além de personagens de uma das mil e uma noites de Sherazade, o que parece convencer o leitor que adquire e lê tais obras é a possibilidade ou a certeza de que a fuga realmente aconteceu da maneira que é ali narrada. Posto isso, analisamos nos excertos selecionados não a veracidade no mundo concreto do que ali se narra, mas, sim, os sentidos discursivos construídos, visto que, a partir da concepção foucaultiana de verdade, entendemos que o regime de verdade é próprio de cada sociedade ou campo do conhecimento, que integra e faz funcionar determinados discursos ou saberes, assim como o que permite a distinção de enunciados verdadeiros dos falsos, ou ainda, quem são aqueles que podem dizer o que funciona como verdadeiro. A esse respeito:

[...] por verdade não quero dizer "o conjunto das coisas verdadeiras a descobrir ou a fazer aceitar", mas o "conjunto das regras segundo as quais se distingue o verdadeiro do falso e se atribui ao verdadeiro efeitos específicos de poder"; entendendo-se também que não se trata de um combate "em favor" da verdade, mas em torno do estatuto da verdade e do papel econômico-político que ela desempenha. (FOUCAULT, MACHADO, 2012, p. 13)

Em uma perspectiva que possa superar o que é ou não verdade sobre a experiência do refúgio, ou ainda sobre a autenticidade do relato de Joude Jassouma, notamos em Eu venho de 
Alepo a construção de sentidos sobre o mundo árabe que se filia à malha discursiva neoorientalista. Tais sentidos parecem se fortificar pela própria escolha do gênero literário da autobiografia, pois, como aponta Said (2016), nas produções orientalistas, há uma condição de autoridade pressuposta àquele que fala sobre o Oriente, ou seja, a autoridade para falar sobre a experiência do refúgio pressupõe a vivência de tal experiência. Na contracapa do livro, há a menção de que "este livro conta a história de um dos milhões de sírios atingidos pela guerra", tal referência parece contribuir para a produção de sentidos que apontem a história narrada em Eu venho de Alepo como um relato de quem de fato detinha de autoridade para contá-la.

Nas narrativas de vida de refugiados sírios, percebemos que a figura do coautor, do escritor colaborador ou daquele que escreve a narrativa, também está sujeita à análise, tanto quanto a figura do refugiado enquanto escritor/narrador de sua própria história. Assim como em outras autobiografias de refugiados sírios, notamos que em Eu venho de Alepo não há uma inequívoca concepção do papel exercido por aquele que participa da escrita da obra com o refugiado. Ao nosso ver, a obra é comercializada como se Laurence de Cambronne exercesse o papel de escritora colaboradora, aquela que participa de maneira secundária desprovida de natureza autoral. A autobiografia em colaboração coloca em questionamento a todo momento em que medida há o "peso da caneta" do escritor colaborador na redação da obra, pois, se há muitos indícios de autoria do escritor colaborador, a autenticidade da narrativa é colocada em risco. A análise aqui proposta não visa definir se há ou não indícios de autoria de Laurence de Cambronne, porém a participação de escritores ocidentais na produção de autobiografias de refugiados sírios exerce importante função na disseminação de tais narrativas. Contar e publicar a história da própria vida tem sido um privilégio reservado a determinadas classes, pois o silêncio de outros segmentos é tido como algo natural - "a palavra é dada a eles - ou seja, tomada deles para ser transformada em escrita" (LEJEUNE, 2014, p. 131) por aqueles que podem escrevê-la (talvez recriá-la, não apenas traduzi-la) e colocá-la em circulação. A construção da legitimidade do refugiado como autor da sua autobiografia se manifesta na condição de que ele detém o conhecimento, a vivência e poder para narrar sua própria história - o que lhe traz valor não ficcional e a dota de verdade. Por outro lado, notamos que tais autobiografias só adquirem permissão (ou possibilidade de) para circular no Ocidente quando 
acompanhadas do assentimento, da escrita oficial, de um coautor ou escritor colaborador ocidental (SOUZA, 2018; BASTOS, 2016).

Para a análise dos excertos extraídos, propomos um estudo do discurso não restrito à análise da materialidade linguística, visto que esta não é o eixo analítico central, mas amparado nas concepções foucaultianas de formação discursiva, relações de poder, verdade e poder (FOUCAULT, 2008; 2012). A geração e a análise dos dados se amparam na abordagem de pesquisa qualitativa, a qual permite ao pesquisador o entendimento, ou interpretação, dos sentidos de um determinado fenômeno social (DESLAURIERS; KÉRISIT, 2012), além dos significados que as pessoas a ele conferem (DENZIN; LINCOLN, 2006). O corpus principal é constituído por excertos textuais e uma figura extraídos do livro Eu venho de Alepo, os quais são analisados através do paradigma interpretativo que é próprio da pesquisa qualitativa. Os excertos foram selecionados a partir das perguntas de pesquisa, no intuito de verificar em que medidas tais trechos poderiam responder as indagações norteadoras deste estudo. A figura analisada é a capa da obra escolhida, que apresenta o rosto do refugiado sírio, elemento que personifica e nos permite perceber como a imagem do refugiado é construída na obra, além de permitir investigar de que maneira o semblante de Joude Jassouma se aproxima ou se distancia da figura retomada no imaginário social acerca do homem árabe.

\section{Autobiografias de refugiados sírios e o discurso neo-orientalista}

No processo de investigação dos sentidos construídos sobre o refúgio, notamos que o gênero autobiográfico induz o leitor a um maior convencimento sobre a veracidade daquilo que é narrado, visto que permite a utilização de procedimentos certificadores da autenticidade do relato, tais como a assinatura, a afirmação da identidade do autor, o modo de escrita, dentre outros (LEJEUNE, 2014). Como se fossem tentativas de escrita da história, as autobiografias de refugiados sírios podem permitir novas verdades, numa acepção foucaultiana da verdade (FOUCAULT, MACHADO, 2012), sobre a guerra na Síria, a categoria de refugiado e a relação Ocidente e Oriente.

Para além dos conceitos teóricos e consolidados sobre quem é o migrante (SAYAD, 1998), entender a construção discursiva sobre aquele que foge forçadamente para outro

Gláuks: Revista de Letras e Artes - jan/jun. 2019 - Vol. 19, $N^{o} 1$ 
território pode perpassar discussões que antecedem sua fuga. No caso do migrante árabe, entendemos que a construção discursiva do outro nas produções orientalistas (SAID, 2004; 2011; 2016) em conjunção com o estado purgatorial do pós-orientalismo após o fatídico Onze de Setembro (DABASHI, 2017) colaboram na perpetuação de discursos sobre tal identidade. Em Orientalismo, SAID (2016) argumenta que a oposição binária entre Ocidente e Oriente é uma construção mútua, ou seja, ao retratar o Oriente enquanto opressor, ressalta-se a liberdade como valor próprio do Ocidente, ou quando se caracteriza este como moderno, aquele é configurado como primitivo. Compreender de que maneira tal discurso pode influenciar na dispersão de estigmas sobre o árabe e, mais especificamente, sobre o refugiado sírio, pode auxiliar o entendimento de muitos dos estereótipos acerca de tais indivíduos.

A esse respeito, Dabashi (2017) aponta que os acontecimentos após o Onze de Setembro, dentre os quais se inserem principalmente as revoluções árabes de 2010, indicam uma mudança de perspectiva que permite novas possibilidades teóricas e temáticas sobre a relação Ocidente e Oriente. Se nas produções orientalistas o Oriente é construído como incapaz de agir no mundo, os eventos pós Onze de Setembro cristalizam o momento de uma mudança epistêmica que permite o surgimento de outros sentidos sobre o Oriente Médio e sua capacidade de autogestão, além da relação ainda fundamentada em relações de poder entre o Ocidente e o Oriente. Para o referido autor, o pós-orientalismo se relaciona com o momento por ele chamado de purgatorial, período em que um estado está em extinção e outro ainda não foi inaugurado, no entanto, nos utilizamos do termo (neo)orientalista, que tem sido o termo utilizado para categorizar produções literárias emergentes deste momento de entremeio, tal qual Eu venho de Alepo, ou as autobiografias de mulheres muçulmanas (BASTOS, 2016).

Os deslocamentos de grandes massas rumo à Europa se expandiram com os conflitos na Síria após 2010. Enquanto força de trabalho, o migrante é visto na sociedade de destino como necessário e útil, uma presença provisória e tolerada (SAYAD, 1998), no entanto sua permanência também reverbera outras particularidades sobre a questão. Os chamados estranhos orientais que batem às portas dos ocidentais retomam a desconfiança atemporal causada pela presença estrangeira e também o medo e desconforto, visto serem representantes de uma alteridade construída histórica e discursivamente como radical. Eles, os estranhos que batem à nossa porta, 
[...] na amarga expressão de Jonathan Rutherford, "transportam as más notícias de um canto distante do mundo para as portas de nossas casas". Eles nos tornam conscientes e nos lembram daquilo que preferiríamos nos esquecer, ou, melhor ainda, fazer de conta que não existe: forças globais, distantes, ocasionalmente mencionadas, mas em geral despercebidas, intangíveis, obscuras, misteriosas e difíceis de imaginar, poderosas o suficiente para interferir também em nossas vidas, enquanto desconsideram e ignoram nossas preferências.

[...] Esses nômades - não por escolha, mas por veredicto de um destino cruel - nos lembram, de modo irritante, exasperante e aterrador, a (incurável?) vulnerabilidade de nossa própria posição e a endêmica fragilidade de nosso bem-estar arduamente conquistado. (BAUMAN, 2017a, p. 20-21)

Em Eu venho de Alepo, é possível que se verifique uma figura de refugiado singular quando comparado aos demais, visto que Joude Jassouma é um indivíduo falante do idioma da sociedade de destino, é escolarizado, já visitara a França, país que o acolheu anteriormente, e não se associa a outras figuras estigmatizadas sobre o homem árabe. Ao contrário de muitos dos outros estranhos que adentram os territórios do mundo ocidental, Joude Jassouma parece ser construído discursivamente em sua autobiografia como um homem diferente da figura presente no imaginário popular ocidental acerca do homem árabe, pois Joude é pacífico, está inserido na cultura francesa, é apresentado distintamente de outros migrantes, sobretudo os não-falantes do idioma francês, na autobiografia analisada.

As migrações forçadas em direção aos Estados ocidentais na última década ecoam a fragilidade de entidades que se pretendem resistentes, como o ideal de Estado-Nação, e provocam o despojamento da vulnerabilidade socioeconômica a que todos estão sujeitos refugiados e membros da sociedade destino. A recorrência de itinerários que apontam os países europeus como as únicas portas possíveis parece indicar a necessidade de legitimação de algumas verdades em detrimento de outras, ou seja, se até poucos anos atrás o ativismo islâmico era visto como fundamentalista radical, a necessidade de convivência entre os diferentes impulsiona a expansão de discursos diferentes daquele. A vulnerabilidade da sociedade destino também é exposta, pois, conforme alude Bauman (2017a, p. 21), os refugiados "nos lembram, de modo irritante, exasperante e aterrador, a (incurável?) vulnerabilidade de nossa própria posição e a endêmica fragilidade de nosso bem-estar arduamente conquistado".

A autobiografia de refugiado sírio se constrói como uma produção situada historicamente que produz sentidos não apenas sobre a vida individual de um refugiado, como também sobre as relações de dominação entre Ocidente e Oriente. Em nosso estudo, a análise 
de excertos de uma produção que entendemos como (neo)orientalista não se trata de investigar a impugnação de erros antigos tampouco o nascimento de novas verdades, mas, em conformidade com Foucault e Machado (2012), entender quais efeitos de poder circulam entre os enunciados, qual o seu regime interior de poder e de que maneira e por que em certos momentos ele se modifica de forma global. As produções neo-orientalistas, em especial as autobiografias, encontram espaço no mercado editorial ocidental, pois o interesse em conhecer as outridades e suas particularidades é algo ainda presente entre os leitores ocidentais a quem tais obras se destinam. Além disso, é marca muito presente nas referidas obras o caráter pedagógico ou a construção narrativa que apresenta um Ocidente moderno versus um Oriente tradicional. Conforme aponta Dabashi (2017), sucessos como Lendo Lolita em Teerã, da iraniana Azar Nafisi, pouco significam no Irã.

\section{Ocidente paradisíaco e Oriente infernal no relato de Jassouma}

As variadas e constantes notícias sobre a crise de refugiados trazem consigo o medo do estranho que bate à nossa porta (BAUMAN, 2017a), especialmente se este migrante tem sua identidade relacionada a construções discursivas ainda latentes no imaginário ocidental que o relacionam a uma alteridade radical. O acolhimento de tais pessoas imbrica a retomada de discursos que até poucos anos atrás os associavam ao terrorismo e barbárie (SOUZA, ZOLIN-VESZ, 2018). Entendemos que as autobiografias de refugiados sírios podem permitir uma reformulação daquilo que o homem árabe representa no imaginário ocidental, além de tornar ainda mais verdadeiro ao leitor o relato da guerra na Síria quando contada por aquele que de fato testemunhou o evento, que o viveu em seu cotidiano.

Em Eu venho de Alepo, o "testemunho ocular" do dia a dia da guerra, da travessia rumo à Europa, é Joude Jassouma, cuja figura é apresentada ao leitor antes mesmo de seu relato, visto que estampa a capa do livro. 


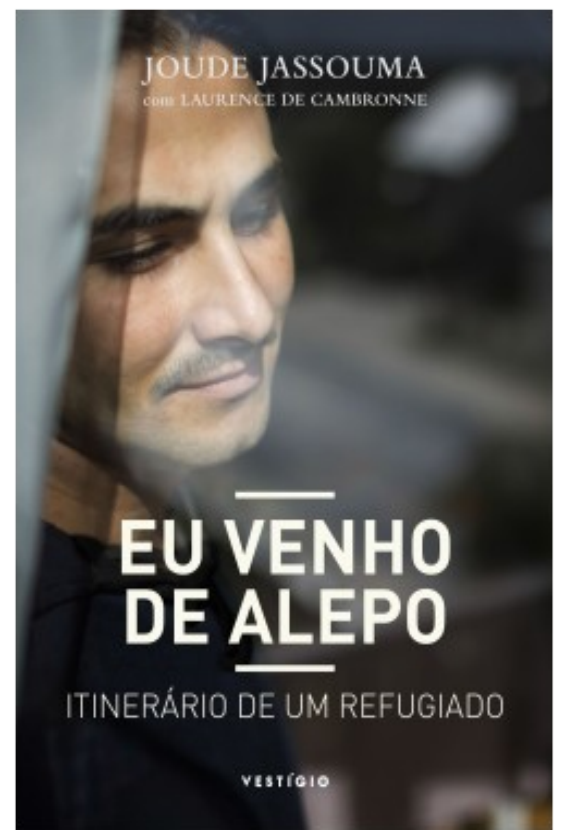

Figura 1 - Capa do livro impresso Eu venho de Alepo

Analisar a capa de uma autobiografia, nesse estudo, justifica-se pela compreensão de que este é o primeiro item a ser lido, olhado, tocado pelo leitor. A capa é um elemento atrativo em um livro, sendo ela, muitas vezes, um dos fatores que convencem o leitor a adquirir o livro em uma livraria, seja ela virtual ou física, ou, nas palavras de Genette (2009, p. 10), enquanto componente paratextual, é aquilo que "oferece a cada um a possibilidade de entrar, ou de retroceder". Tal qual no diário íntimo com cadeado, na autobiografia impressa a curiosidade do leitor pode ser estimulada ou não a depender de sua capa.

A capa de Eu venho de Alepo ilustra o rosto de Joude Jassouma, cujo olhar não encara o leitor, em seu semblante não vemos sorriso ou excitação, é uma imagem que personaliza e individualiza o refugiado sírio. Antes mesmo de ler sua história de vida, já sabemos que ele é um homem, jovem, de pele clara, com um semblante que aparenta tranquilidade e, principalmente, ele não se assemelha à figura do árabe com longa barba, olhar firme, com turbante na cabeça e vestimentas características. Entendemos que tal representação é uma das primeiras a possibilitarem a desconstrução do preconceito de que o homem do Oriente Médio seria um extremista radical, alguém para quem as portas do Ocidente precisam ficar fechadas. 
Acreditamos que o título Eu venho de Alepo: itinerário de um refugiado confirma que se trata de uma obra direcionada ao leitor ocidental, pois Jassouma vem de "lá" - do Oriente - para "cá" - o Ocidente. Em um momento em que há o interesse sobre as questões relacionadas à guerra na Síria, o título nos convida a conhecer a história deste sobrevivente, e ainda, o testemunho ocular da guerra civil da Síria. É possível depreender pelo título que ele "veio da guerra", pois a obra surge em momento em que ainda são latentes os eventos da guerra civil síria, permitindo que seja retomado no imaginário ocidental a imagem que associa Alepo à guerra.

A relação entre Alepo e a guerra se confirma no relato de Jassouma, uma vez que há diversos elementos que constroem a Síria como espaço de hostilidade e desumanidade. Em grande parte da obra, há relatos sobre como e onde iniciaram os primeiros conflitos que desencadearam a guerra, além do cotidiano de sua família, a qual é descrita por Jassouma como insuportável e infernal, visto que, por terem as residências bombardeadas, vinte e três familiares, dentre as quais Joude, conviviam em uma casa de três cômodos, tal qual verificamos no enunciado abaixo:

\section{Enunciado 1}

Vivíamos amontoados como gado. Gritos e discussões o tempo todo. Os filhos do meu irmão mais velho choravam. Meus irmãos mais velhos brigavam. A vida cotidiana era infernal. (JASSOUMA, p. 59, 2017)

A exposição da rotina e dos problemas de convivência entre tantas pessoas em um ambiente tão pequeno demonstra a instabilidade social derivada da guerra, pois as dificuldades econômicas se maximizaram quando a casa anterior foi bombardeada e a família perdeu seus bens materiais. A escrita de si, manifestada quando Jassouma caracteriza a vida cotidiana como "infernal", permite que a narrativa de sua vida íntima transporte o leitor para uma experiência de entendimento dos efeitos da guerra para os sírios comuns, aqueles que não estavam em combate nem associados às forças envolvidas na guerra. Apesar de a descrição do cotidiano da família Jassouma também se assemelhar ao de pessoas em situação econômica de pobreza, principalmente em grandes cidades, tal relato parece preencher as lacunas sobre o que seria a guerra na Síria: se, de um lado, há o ditador e, de outro, os islamistas, certamente o chão da arena é composto pelas vítimas - sem culpa, sem forças e frágeis (SOUZA, 2018).

$\mathrm{O}$ enunciado 2 também apresenta as complicações da guerra, que vão além das dificuldades econômicas e da vulnerabilidade social - a violência é diária: 


\section{Enunciado 2}

Todos os dias, os aviões faziam rasantes sobre o nosso prédio.

Todos os dias, mísseis passavam por cima de nossas cabeças.

Todos os dias, ouvíamos os helicópteros de Bashar que saíam para lançar barris de explosivos.

Todos os dias, temíamos os tiros de morteiro que caíam, ora longe, ora perto.

Todos os dias, descíamos para nos abrigar no porão. (JASSOUMA, 2017, p. 71)

Notamos que a ininterrupção da guerra é ressaltada pela repetição de "todos os dias", pois a guerra não tinha acabado enquanto tantas outras coisas aconteciam na vida de Joude Jassouma: ele casou-se, gozou de felicidades em sua lua de mel, tornou-se pai, mudou diversas vezes de residência. A impossibilidade de viver naquele espaço é destacada ao reiterar que as condições de existência na Síria já tinham se tornado insustentáveis e insuportáveis, logo tais condições de existência se tornam também as motivações para a fuga não só de Joude Jassouma como também dos milhares de refugiados que partiram da Síria. $\mathrm{O}$ excerto apresenta o medo vivenciado na Síria da guerra: os sons de tiros, helicópteros, aviões fazendo rasantes, bombardeios, ocupam o lugar do silêncio, dos sons próprios da ordinária vida urbana, a qual, possivelmente, é experimentada pelo leitor ocidental. Esse enunciado também aponta razões para o refúgio, afinal somente o instinto de sobrevivência para justificar que um ser humano cruze o mar sem saber nadar, atravesse um deserto sem orientação, pilote um bote sem habilidade para tal.

O itinerário de Joude Jassouma é longo, visto que, até chegar na França, ele passa por 119 checkpoints na Síria, cruza a Turquia, passando por diversas cidades do país, até se estabelecer em Istambul, onde fica por 2 meses até conseguir recursos financeiros para a viagem de sua esposa. A situação de vulnerabilidade social e pobreza estimula Joude e sua esposa Aya a decidirem ir para a Europa. Os discursos que constroem a Europa como o lugar da liberdade, da paz, da prosperidade em conjunto com as dificuldades socioeconômicas vivenciadas na Síria e nas regiões de trânsito provisório, parecem ser impulsionadores para as viagens nas mais adversas condições rumo ao continente europeu. A família, Joude, Aya e a filha do casal de 8 meses, atravessaram o mar Egeu da forma mais usual entre as várias fugas de sírios rumo a Europa: em um bote inflável. Superada a difícil travessia, em que visualizam outro bote se afundando, a chegada ao solo grego dá início aos relatos da vida ocidental almejada pela família. 


\section{Enunciado 3}

O mar começava a nos esquentar, o mar tinha reflexos azul celeste. Estava bonito, calmo, já não nos provocava medo.

$[\ldots]$

Esse dia 5 de março de 2016 ficará para sempre gravado na minha memória como o primeiro dia da minha nova vida. Um lindo dia de sol em que uma nova palavra passou a fazer parte do meu vocabulário, a palavra "paz". (JASSOUMA, 2017, p. 92-95)

O enunciado 3 traz as primeiras impressões de Joude após concluírem a travessia do Mar Egeu. O mar "bonito, calmo" e que já provocava medo era ainda o mesmo que haviam atravessado, porém a perspectiva de vê-lo a partir do solo europeu permite a sua ressignificação. A visão do mar a partir do solo oriental representava o medo de quem não sabia se iria concluir a travessia, vê-lo a partir do bote sobre o mar era o constante embate entre o medo da morte e a esperança da vida na Europa, no entanto vê-lo já na segurança proporcionada pelo solo ocidental era enxergá-lo como calmo e bonito. Notamos que tal enunciado parece ressaltar a superação de um estado de opressão ou sensação de alívio, experiências que só poderiam ser concretizadas longe da Síria da guerra e no amparo da Europa da paz.

A recorrência de "nova" em referência à vida na Europa e à palavra paz apresenta uma renovação, pois a paz e a tranquilidade só encontram espaço para existirem na Europa para Jassouma, o que se confirma com a menção de que naquele dia seu vocabulário ganhou uma palavra até então desconhecida, o que podemos entender como uma metáfora para sua vida e seu estado de espírito. A busca por tais sentimentos e sensações é também o que motiva milhares de pessoas a fugirem de seu território rumo à Europa. Os fluxos migratórios daqueles que buscam guarida após a instalação da guerra em seus territórios, bem como de migrantes econômicos, evidenciam um fenômeno que não é recente e que ainda não caminha para seu término (BAUMAN, 2017a).

Na narrativa de Jassouma, é possível também perceber que a Europa da liberdade e do progresso pode ser também incapaz de abrigar o grande contingente de imigrantes ou ainda não ser tão acolhedora quanto pretende ser, conforme verificamos no enunciado 4 :

\section{Enunciado 4}

Ao meu redor, o espetáculo é desolador. Roupas secando em cordas estendidas entre as tendas, mulheres sentadas no chão. Não foi disso que vim atrás, não deixei a guerra para encontrar a miséria, não quero viver na Europa se é para morar na rua. (JASSOUMA, 2017, p. 102) 
O enunciado 4 apresenta a percepção de Jassouma sobre as dificuldades encontradas pelos refugiados no território grego, bem como a incapacidade de abrigar tantas pessoas ou ainda o real espaço do imigrante na sociedade de destino. A imagem da Europa como a única saída para ter uma nova vida livre e em paz é tomada por outras possibilidades de existência do mesmo território. Ao afirmar que não deixou a guerra para encontrar a miséria, Jassouma parece colocar em conflito a visão de um Ocidente acolhedor. Tal visão, ou ainda tal discurso, tem potência enquanto (re)produtor de sentidos, pois os milhares de refugiados que cruzaram o Mar Egeu, em situação de inegável insegurança, sem garantias de como seria a vida na Europa, também não deixaram a guerra para viverem na miséria. Assim como a família Jassouma, partiram em direção a uma esperança incerta de que gozariam das benesses de uma vida ocidental, a qual é construída discursivamente como livre, democrática, pacífica.

Eu venho de Alepo não explora a situação de vulnerabilidade vivenciada pelos refugiados na mesma proporção em que transmite a visão de uma Europa acolhedora, pois a situação descrita no enunciado 4 é apresentada como restrita aos grupos que insistiam em escolher determinado país de destino. Pela autobiografia de Jassouma, é possível inferir que, se aquelas pessoas fossem mais flexíveis, não estariam ali amontoadas e vivendo em situação lastimável. Se deixassem que o Ocidente escolhesse seus destinos e os salvasse, estariam todos em melhores condições nos países que se dispusessem a acolhê-los. Joude e sua família aceitam participarem do programa de recolocação, ou seja, seriam escolhidos pelo país que lhes aceitaria. Por sorte, foram escolhidos pela França.

\section{Enunciado 5}

Gostaria de ser um membro ativo da sociedade francesa. Gostaria de restituir à França um pouco de tudo aquilo que ela me deu. Ainda não sei como, mas hei de encontrar uma maneira.

Minha nova vida começa aqui. Não quero mais olhar para trás.

(...)

Daqui para frente, meu sonho é me integrar à França, me adaptar a sua cultura. Quero viver à francesa. Viver como os franceses.

Nos meus sonhos mais loucos, chego a me imaginar reitor de uma universidade francesa! Mas se tivesse apenas um desejo a formular, seria o de que um dia, na França, ninguém mais me considere como um "refugiado". (JASSOUMA, 2017, p. 133)

$\mathrm{O}$ enunciado 5 encerra o relato de Jassouma e parece firmar o entendimento de que no Ocidente é possível renascer, ter uma nova vida, sendo este portanto um território sobre o qual ele guarda gratidão e espera fundir-se, inclusive, com a identidade cultural desse espaço. 
Querer ser um membro ativo na França retoma o discurso da migração sobre o imigrante e o desemprego, cujos efeitos de sentido recaem sobre o imigrante que é entendido como alguém que precisa ser um participante efetivo na sociedade destino, uma mão de obra útil (SAYAD, 1998) e, também, grato por toda ajuda fornecida. Ao nosso ver, tal gratidão pode reafirmar o papel do refugiado como alguém que sempre estará em débito com o país que o acolheu.

A afirmação de que sua nova vida começa aqui e que não quer mais olhar para trás também produz efeitos de sentido sobre a relação Ocidente e Oriente. De um lado, há um Oriente, que representa a hostilidade, a miséria, a guerra, a opressão, o regime ditatorial e outros atributos negativos; de outro, um Ocidente, que reflete os ideais de liberdade, prosperidade, paz, a democracia e torna realidade uma vida completamente nova e oposta da anterior. O advérbio "aqui" pode ser compreendido como o espaço físico em que Jassouma inicia a nova vida - a França - ou ainda como a marcação temporal do momento presente - o agora. Semelhante parece ocorrer com a locução adverbial "para trás", a qual pode ser entendida em duplo significado, visto que Jassouma não quer mais olhar para a Síria, o lugar de onde veio, bem como não quer também olhar para tudo o que já viveu - o passado. Ambos os sentidos vertem para a dicotomia que sustenta o discurso (neo)orientalista em sua dimensão espacial (lá e cá) e temporal (a tradição antiga e a modernidade).

No enunciado acima, percebemos também que "daqui para frente" aclara a possível existência de uma dimensão temporal indicativa do afastamento do passado miserável na Síria a fim de se tornar cada vez mais conectado ao futuro promissor na França. A vontade de se adaptar não nos parece limitada à integração quanto às regras, aos modos de convívio, mas, para além disso, ao desejo de uma união à cultura francesa para se tornar menos oriental e mais ocidental. Tal enunciado também denota o posicionamento da identidade europeia como superior às demais, ou ainda da liberdade ocidental como liberdade condicionada, visto que o refúgio não parece significar a vivência de sua cultura e identidade em outro território. "Viver à francesa" e "viver como os franceses" sugerem que esse modo de vida é de fato positivo, pois ser mais francês e menos sírio, ou ainda mais cidadão francês e menos refugiado, sugere o anseio pela invisibilidade de sua outridade, visto que esta traz em si sentidos que a subalternizam perante a identidade ocidental.

Se autobiografias são modos de tornar memoráveis existências singulares, são também produções e ações no mundo, visto que, pela e na linguagem, nos e pelos discursos, 
também podemos construir sentidos sobre o mundo social. A proximidade dos opostos é desestabilizadora, afinal não se sabe o que esperar do outro e descobrir as compatibilidades é uma tentativa desafiadora (BAUMAN, MAURO, 2016). As diferenças existem e são inegáveis muitas vezes, no entanto estruturas fundamentadas em colunas "nós" e "os outros", ao nosso ver, distanciam, violentam e impossibilitam a descoberta de compatibilidades.

\section{Um momento purgatorial: ponto ou vírgula?}

Os resultados sugerem que Eu venho de Alepo se afilia à formação discursiva (neo)orientalista na medida em que constrói uma narrativa-mestra sobre a migração forçada: o Ocidente é (re)produzido como o espaço da liberdade e da paz de maneira a ignorar as intempéries e infortúnios pelos quais muitos dos refugiados passam ao buscarem o refúgio na Europa, em especial aqueles que não detém o nível de informação, de escolaridade e domínio do idioma tal qual Joude Jassouma. Apesar de Eu venho de Alepo ser comercializado como a primeira narração da "maior crise migratória desde a Segunda Guerra Mundial”, conforme consta na orelha do livro, a experiência de Joude Jassouma não pode ser entendida como uma história única que visa explicar a guerra na Síria e os consequentes deslocamentos de grandes grupos de sírios rumo à Europa, ao contrário, é mais um dos tantos entendimentos possíveis sobre o referido evento. Os efeitos de sentido produzidos são diversos, pois, ao mesmo tempo em que sistemas de pensamento como o (neo)orientalismo reforçam a violência estrutural e marginaliza outros modos de vida, a questão do refúgio pode incentivar a solidariedade voluntária nas sociedades de destino. A troca de vivências entre refugiados e voluntários é narrada por Jassouma (2017) como algo positivo e humano, desprovido dos preconceitos clássicos contra o homem árabe. Narrativas como Eu venho de Alepo ressaltam o momento purgatorial (DABASHI, 2016) em que nos inserimos, quando nos é permitido apenas duas alternativas - ou nos damos as mãos ou estamos todos perdidos (BAUMAN, 2017b).

Gláuks: Revista de Letras e Artes - jan/jun. 2019 - Vol. 19, $N^{o} 1$ 


\section{Referências bibliográficas}

BASTOS, L. M. P. C. Fetiche neo-orientalista: o problema da autorrepresentação do subalterno e as autobiografias de mulheres muçulmanas. Goiânia: Editora UFG, 2016.

BAUMAN, Z. Estranhos à nossa porta. Tradução Carlos Alberto Medeiros. $1^{\mathrm{a}}$ ed. Rio de Janeiro: Zahar, 2017a.

$2017 \mathrm{~b}$.

Retrotopia. Tradução Renato Aguiar. 1a ed. Versão Kindle. Rio de Janeiro: Zahar,

BAUMAN, Z.; MAURO, E. Babel. Tradução Renato Aguiar. 1a ed. Rio de Janeiro: Zahar, 2016.

COSTA, R. P. Uma história da Síria do século XXI para além do sectarismo religioso. $136 \mathrm{f}$. Dissertação (Mestrado em Estudos Árabes) - Faculdade de Filosofia, Letras e Ciências Humanas, Universidade de São Paulo, São Paulo, 2016. Disponível em: <doi:10.11606/D.8.2016.tde-24082016-153949>. Acesso em: 09 mar. 2019.

DESLAURIERS, J. P., KÉRISIT, M. O delineamento de pesquisa qualitativa. In: POUPART, Jean, et al. A pesquisa qualitativa - enfoques epistemológicos e metodológicos. Tradução de Ana Cristina Nasser. 3. ed. Petrópolis(RJ): Vozes, 2012, p. 127-153

DENZIN, N. K.; LINCOLN, Y. S. O planejamento da pesquisa qualitativa: teorias e abordagens. Tradução Sandra Regina Nietz. Porto Alegre: Artmed, 2006.

DABASHI, H. Post-orientalism: knowledge and power in a time of terror. Kindle Edition. New York: Routledge, 2017.

FOUCAULT, M. A arqueologia do saber. Tradução Luiz Felipe Baeta Neves. $7^{\mathrm{a}}$ ed. Rio de Janeiro: Forense Universitária, 2008.

FOUCAULT, M.; MACHADO, R. (Org.). Microfisica do poder. 25. ed. São Paulo: Graal, 2012.

JASSOUMA, J. Eu venho de Alepo: itinerário de um refugiado. Colaboração de Laurence de Cambronne. Tradução Fernando Scheibe. 1a ed. São Paulo: Vestígio, 2017.

LEJEUNE, P.; NORONHA, J. M. G. (org.). O pacto autobiográfico: de Rousseau à internet. Tradução Jovita Maria Gerheim Noronha e Maria Inês Coimbra Guedes. 2. ed. Belo Horizonte: Editora UFMG, 2014.

SAID, E. W. Orientalismo: o Oriente como invenção do Ocidente. Tradução Rosaura Eichenberg. 6a. reimp. São Paulo: Editora Companhia das Letras, 2016.

Gláuks: Revista de Letras e Artes - jan/jun. 2019 - Vol. 19, $N^{o} 1$ 
Fora de lugar: memórias. Tradução José Geraldo Couto. São Paulo: Editora Companhia das Letras, 2004. $\overline{\text { Bolso, } 2011 .}$

Cultura e Imperialismo. Tradução Denise Bottmann. São Paulo: Companhia de

SAYAD, A. Imigração ou os paradoxos da alteridade. Tradução Cristina Murachco. São Paulo, Edusp, 1998.

SOUZA, D. S. Eu venho de Alepo: O discurso (neo) orientalista na (auto)biografia de um refugiado sírio. $92 \mathrm{f}$. Dissertação (Mestrado em Estudos de Linguagem). Universidade Federal de Mato Grosso, Cuiabá, 2018. Disponível em $<$ https://www.ufmt.br/ppgel/index.php?

option $=$ com_content\&view $=$ article $\&$ id $=93 \&$ Itemid $=304 \&$ lang $=p t-b r>$. Acesso em: 14 mar. 2019.

SOUZA, D. S.; ZOLIN-VESZ, F. Da hospitalidade à intolerância ao migrante árabe: construções discursivas sobre um mesmo Brasil. Trabalhos em Linguística Aplicada, Campinas, v. 57, n. 2, p. 877-893, ago. 2018. Disponível em $<$ http://www.scielo.br/scielo.php?script=sci_arttext\&pid=S0103-18132018000200877\&lng=p t\&nrm=iso $>$. Acessos em:19 mar. 2020. 


\begin{abstract}
The Civil War in Syria since 2011 and the humanitarian crisis of refugees have been highlighted in the plot of Syrian refugee autobiographies in the international publishing market. This article seeks to analyze the (neo)orientalist discourse in the autobiography Eu venho de Alepo of Joude Jassouma in order to present possible understandings about the effects produced on the Syrian refugee and on the relation West and East. The study of discourse is based on the Foucaultian conceptions of discursive formation, enunciation, relations of power, truth and power (FOUCAULT, 2008; FOUCAULT, MACHADO, 2012). This research is guided by two questions: how is the Syrian refugee presented in Eu venho de Alepo? What are the meanings produced on the relation West and East in this work? The results suggest that Eu venho de Alepo joins the (neo) orientalist discursive formation insofar as it builds the West as the space of freedom and peace and the East as the space of war and barbarism. The effects of sense produced are diverse, for just as systems of thought such as (neo) Orientalism reinforce structural violence and marginalize other ways of life, refuge can encourage voluntary solidarity.
\end{abstract}

Keywords: Refugee. Syria. Autobiography. Neo-orientalism. 